\title{
Screening and management of thyroid dysfunction in preterm infants
}

\section{Hye Rim Chung, MD}

Department of Pediatrics, Seoul National University Bundang Hospital, Seongnam, Korea
Received: 29 January, 2019

Revised: 14 March, 2019

Accepted: 15 March, 2019

Address for correspondence: Hye Rim Chung, MD

Department of Pediatrics, Seoul National University Bundang Hospital, 82, Gumi-ro 173 Beongil, Bundang-gu, Seongnam 13620, Korea

Tel: +82-31-787-7289

Fax: +82-31-787-4054

E-mail: chyerim@hanmail.net

http://orcid.org/0000-0001-85504969
Preterm infants can suffer various thyroid dysfunctions associated with developmental immaturity of the hypothalamic-pituitary-thyroid axis, postnatal illness, medications, or iodine supply. The incidence of thyroid dysfunction among preterm infants is higher than that among term infants and has been increasing with improvement in the survival of preterm infants. Hypothyroxinemia is frequently observed during the first week of life in extreme preterm neonates, and the incidence of delayed thyrotropin elevation is high at the age of 2-6 weeks. Although the necessity of routine rescreening remains controversial, recent guidelines on screening for congenital hypothyroidism have recommended rescreening of all preterm neonates. Thyroid hormone replacement is recommended for persistent thyrotropin elevation with or without hypothyroxinemia. Hypothyroxinemia without thyrotropin elevation does not require treatment, and some potential risks of levothyroxine supplementation have been reported. Although most thyroid dysfunctions are transient, careful follow-up after discontinuation of levothyroxine is considered so as to avoid missing persistent hypothyroidism.

Keywords: Thyroid, Preterm infant, Hypothyroidism, Hypothyroxinemiasequencing, Short stature

\section{Introduction}

Thyroid hormone is essential for the growth and development of infants. A profound deficiency of thyroid hormone during the early period of life is the leading cause for mental retardation, which is preventable with proper treatment. The importance of early diagnosis and treatment of congenital hypothyroidism, which was highlighted through the first neonatal screening program for congenital hypothyroidism, was established in the mid-1970s in Quebec, ${ }^{1)}$ such a screening program is now conducted in many countries. In South Korea, a government-led neonatal screening program began in the early 1990s, and a nation-wide screening program was established in the mid-2000s. ${ }^{2}$ Although there is considerable amount of historic data regarding screening programs for congenital hypothyroidism, the standard methods still remain controversial. ${ }^{3)}$

The incidence of premature birth is increasing, and advances in neonatal care have improved the survival of preterm neonates who present thyroid dysfunction more frequently than term neonates. Preterm neonates are considered as a special category of neonates who are at a risk of congenital hypothyroidism. ${ }^{4.5)}$ In 2014, the European Society for Pediatric Endocrinology (ESPE), on behalf of all pediatric endocrinologist societies worldwide, published updated guidelines on congenital hypothyroidism and recommended rescreening for congenital hypothyroidism among all preterm neonates. ${ }^{5}$ Other recent guidelines, such as those published in the Japanese Society for Pediatric Endocrinology and Indian Society for Pediatric and Adolescent Endocrinology, have also specified methods of screening for preterm infants. ${ }^{6.7)}$ However, the optimal management of thyroid dysfunction among preterm neonates 
remains unclear.

This article reviews the characteristics of thyroid function in preterm infants, compares recent guidelines regarding screening for congenital hypothyroidism among preterm infants, and determines the challenges regarding thyroid dysfunction in preterm infants that need to be addressed.

\section{The characteristics of thyroid function in preterm infants}

The postnatal thyrotropin (TSH) surge is blunted and serum thyroxine (T4) concentration is frequently low at 1-2 weeks of postnatal life in preterm neonates. ${ }^{8-10)}$ In addition, delayed TSH elevation from normal TSH levels are observed in the initial tests among some preterm infants. ${ }^{10,11)}$

\section{Transient hypothyroxinemia of prematurity}

Transient hypothyroxinemia of prematurity (THOP) is characterized by transiently low levels of circulating thyroid hormones along with normal TSH levels. ${ }^{10)}$ The depth of the nadir and length of time before the recovery of THOP are related to gestational age (GA). THOP usually resolves within $2-3$ weeks accompanied with progressive maturation of the hypothalamic-pituitary-thyroid (H-P-T) axis. ${ }^{10)}$ The prevalence of THOP has been reported to be $35 \%-85 \%$ among very preterm infants. ${ }^{12)}$ Blunted TSH surge after birth, decreased hepatic production of T4-binding globulin, reduced iodine storage, dopamine administration, high-dose steroid therapy, exchange transfusion, and undernutrition contribute to THOP development. ${ }^{9-13)}$

Although transiently low levels of thyroid hormones are associated with high incidence rates of cerebral palsy and cognitive impairment in preterm infants, ${ }^{14)}$ previous studies have not demonstrated any clear advantages of thyroid hormone replacement. ${ }^{15-18)}$ The current recommendation is to administer thyroid hormone alone to infants with THOP if the condition is characterized by elevated TSH levels. ${ }^{6,19)}$

When a preterm neonate presents low T4 levels along with normal or low TSH levels, a differential diagnosis for central hypothyroidism should be made in certain clinical situations. A thyrotropin-releasing hormone (TRH) stimulation test might differentiate them because the response of infants with THOP to TRH stimulation test is not different to that of euthyroid infants. ${ }^{20)}$

\section{Delayed TSH elevation}

Transient TSH elevation for several weeks after birth is predominant among preterm infants, low birth weight (LBW) infants, and very LBW (VLBW) infants. This phenomenon is called "delayed TSH elevation" or "atypical hypothyroidism." It usually occurs at 2-6 weeks of age and most cases resolve at 6-10 weeks of age. $^{11)}$

The etiology of delayed TSH elevation remains unclear. An elevated TSH concentration may reflect true primary hypothyroidism or the recovery of illness-induced suppression of the H-P-T axis. Iodine deficiency or excess iodine levels are associated with the development of delayed TSH elevation in some preterm infants. ${ }^{10,11,21)}$

According to an Italian study, delayed TSH elevation reportedly affected $0.2 \%$ of LBW infants. ${ }^{22)}$ In South Korea, delayed TSH elevation requiring levothyroxine replacement was reported in $7.6 \%$ of infants with a GA of $<32$ weeks and in $8.9 \%$ of infants with a birth weight of $<1,500 \mathrm{~g} .{ }^{23,24)}$ Delayed TSH elevation is more frequent in infants with a lower GA, lower birth weight, or a serious illness. In a study performed in New England, the incidence of delayed TSH elevation was 1 in 58 for extremely low-birth-weight infants, 1 in 95 for VLBW infants, and 1 in 30,329 for LBW infants. ${ }^{25)}$

Levothyroxine supplementation is usually recommended for TSH elevation and/or low T4 level. ${ }^{3,19,26)}$

\section{The main factors that affect thyroid function in preterm infants}

Thyroid function in preterm infants reflects the relative immaturity of the H-P-T axis found in the fetuses with a comparable GA. Environmental factors also influence thyroid function in preterm infants. Table 1 summarizes the factors that affect thyroid function in preterm infants.

\section{Developmental immaturity}

During fetal life, circulating levels of T4 and triiodothyronine (T3) are low, whereas those of the inactive metabolites, reverse T3 (rT3) and T3 sulfate, are high. This is a consequence of both the immaturity of the H-P-T axis and coordinated adjustments in the deiodinase system. The maturation of the H-P-T axis continues until late gestation. ${ }^{9,10)}$ The activity of type 1 iodothyronine deiodinase (D1) is low, and the levels of type 2 deiodinase (D2) and type 3 deiodinase (D3) are high throughout gestation. ${ }^{25)}$ The near-term increase in fetal cortisol and T4 levels induces tissue D1 activities and reduces the levels of D2 and sulfotransferase. This change is limited prior to 30 weeks, which results in low serum levels of T3 and relatively high levels of inactive rT3 and sulfated iodothyronines in preterm neonates. The increasing levels of free T4 stimulate

Table 1. Factors that influence preterm thyroid function

Loss of maternal and placenta-supplied hormones: loss of maternal T4
Hypothalamic-pituitary immaturity
Limited thyroid gland reserve due to small thyroid gland
Persistent fetal thyroid hormone metabolism
lodine imbalance
Predisposition to nonthyroidal illness: medications, and adverse
perinatal events


hepatic D1 activity in preterm infants, but this phenomenon requires several weeks. ${ }^{10,27,28)}$ The serum concentration of thyroxine-binding globulin, prealbumin, and albumin are low in preterm infants, which is associated with low serum T4 level. ${ }^{13,29)}$

The thyroid gland of preterm neonates is smaller than that of term neonates. The mean value of thyroid weight in preterm neonates of GA 24-32 weeks was reported to be $0.44 \mathrm{~g}$ vs. 1.79 g in term neonates. ${ }^{30)}$ According to the size of the thyroid gland, thyroid hormone synthesis and storage capacity as well as iodine content in preterm neonates are lower than those in term neonates. A small thyroid gland as well as low thyroid hormone and iodine reservoirs are associated with the development of thyroid dysfunction when thyroid hormone requirement rapidly changes or iodine imbalance occurs.

\section{Environmental factors}

Various medications, particularly dopamine and steroids, affect thyroid function (Table 2) Neonatal morbidity, such as respiratory distress syndrome and malnutrition, also affects thyroid function in preterm infants. ${ }^{10,23,31)}$

Preterm neonates have a narrow range for safe iodine intake. Studies conducted on healthy preterm and full-term newborns led us to believe that the iodine intake required to maintain a positive balance is $15 \mu \mathrm{g} / \mathrm{kg}$ per day among full-term newborns and $30-60 \mu \mathrm{g} / \mathrm{kg}$ per day among preterm neonates. ${ }^{32)}$ Preterm neonates are more vulnerable to thyroid dysfunction caused by iodine deficiency than term neonates because of a much lower

\begin{tabular}{l} 
Table 2. Medications that influence thyroid function \\
\hline Drugs that decrease TSH secretion \\
Dopamine \\
Glucocorticoids \\
Octreotide \\
Drugs that decrease or increase thyroid hormone secretion \\
lodide \\
Amiodarone \\
Drugs that increase TBG concentration \\
Estrogen \\
Drugs that decrease TBG concentration \\
Androgen \\
Glucocorticoid \\
Drugs that displace from protein-binding site \\
Furosemide \\
Salicylate \\
Drugs that increase hepatic metabolism \\
Phenobarbital \\
Phenytoin \\
Carbamazepine \\
Drugs that decrease T4 $5^{\prime}$-deiodinase \\
Prophylthiouracil \\
Amiodarone \\
$\beta$-Adrenergic antagonist \\
Glucocorticoid \\
\hline TSH, thyrotop;
\end{tabular}

$\mathrm{TSH}$, thyrotropin; TBG, thyroxine-binding globulin. capacity of the thyroid gland of preterm neonates to retain iodine. ${ }^{10)}$ Studies on iodine balance have shown that most sick or extreme-preterm neonates have iodine deficiency. ${ }^{33-35)}$ This is particularly significant in iodine-deficient areas worldwide. Meanwhile, preterm neonates are vulnerable to thyroid suppression caused by excess iodine levels. ${ }^{36-38)}$ Impaired iodine organification in the human fetus can increase the Wolff-Chaikoff effect, and escape from the Wolff-Chaikoff effect seems to appear at a GA of $>35$ weeks among preterm infants. ${ }^{39)}$ Neonatal exposure to iodine-containing disinfectants causes thyroid dysfunction among infants born at $<32$ weeks. ${ }^{40)}$ Maternal iodine intake is related to iodine content in breast milk. ${ }^{37,41)}$ Excessive iodine in breast milk is associated with subclinical hypothyroidism among preterm infants. ${ }^{38)}$

Enteral iodine intake at $30-100 \mu \mathrm{g} / \mathrm{kg}$ per day is widely accepted for preterm infants, whereas that for term infants ranges from 15 to $150 \mu \mathrm{g} / \mathrm{kg}$ per day. ${ }^{33,42,43)}$ The recommended parenteral intake of iodine is $1 \mu \mathrm{g} / \mathrm{kg}$ per day, which is far below the requirement for preterm neonates. ${ }^{44-46)}$

\section{Controversies regarding congenital hypothyroidism screening}

There are 2 major screening strategies targeted toward the detection of congenital hypothyroidism: primary T4/ backup TSH method and primary TSH method. A primary T4/backup TSH program is favorable for the detection of hypothyroxinemia, although this method is unable to detect subclinical hypothyroidism or normal T4 with delayed TSH elevation. Meanwhile, the primary TSH program overlooks the detection of hypothyroxinemia without TSH elevation, and a single TSH program will also overlook delayed TSH elevation. The primary T4/backup TSH program is favored in North America, and the primary TSH program is favored in most parts of Europe and Asia including Korea. According to the ESPE guidelines, primary TSH screening is the most sensitive test for detecting primary congenital hypothyroidism.

Most programs collect one blood sample within the first week of life. However, the reliability of a single screening is particularly low among preterm neonates than among term neonates because preterm neonates frequently present with transient hypothyroxinemia and lack a predictable pattern of TSH secretion. Thus, recent screening guidelines for congenital hypothyroidism have recommended routine rescreening of preterm neonates (Table 3). ${ }^{4,7,47)}$

However, not all centers have adopted the routine rescreening strategy based on the following considerations: (1) VLBW newborns with permanent primary hypothyroidism can mount an appropriate TSH response, (2) most of the thyroid dysfunctions are transient problems, and (3) the benefits of treatment for mild thyroid dysfunction remain unproven. ${ }^{25,48)}$ Moreover, rescreening of all preterm neonates adds to the stress of frequent samplings and a high economic burden.

Therefore, stratified screening according to the GA or birth weight or initial screening result warrants investigation. 
LaFranchi ${ }^{49)}$ suggested a routine repeated screening test for neonates having a birth weight of $<1,500 \mathrm{~g}$ or GA of $<32$ weeks. Korada et al. ${ }^{50)}$ reported that in case of an initial blood TSH level of $<6 \mathrm{mU} / \mathrm{L}$, no thyroid abnormalities requiring treatment were noted; thus, a second sample might not be necessary for a screening threshold of $6 \mathrm{mU} / \mathrm{L}$. Nonetheless, it is challenging to determine the categories that do not require repeated screening because the TSH values of preterm neonates are usually unpredictable.

Rescreening is mostly performed at the age of 2-4 weeks when a delayed TSH elevation is prominent. A few programs have recommended repetition of the rescreening procedure at a 1-month interval because extremely premature infants can subsequently develop hypothyroidism. However, the longterm outcome data are limited for infants who had normal first or second screening results but subsequently experienced an elevation in TSH levels. ${ }^{25)}$

\section{Issues on thyroid hormone replacement}

The interpretation of screening result is another problem. Some screening programs have suggested similar cutoffs for TSH or T4 among term and preterm infants, ${ }^{7)}$ while others have recommended use of normal values for thyroid hormones and TSH according to GA and postnatal age..$^{27,49,51)}$ In 2006, the American Academy of Pediatrics suggested a reference TSH range of 1.7-9.1 $\mathrm{mU} / \mathrm{L}$ for preterm infants at the age of 2-6 weeks. ${ }^{4)}$ However, this does not mean that TSH levels above the reference value adversely affect the health of infants. Woo et al. ${ }^{25)}$ reported that preterm infants with an elevated TSH level of $<50 \mathrm{mIU} / \mathrm{L}$ (mean, $21 \mathrm{mU} / \mathrm{L}$ ) were not treated, and the growth and neurological outcomes of infants with delayed TSH elevation were similar to those of control infants at 18-month follow-up. Considering that the major purpose of neonatal screening for congenital hypothyroidism is the detection of neonate with severe hypothyroidism who would develop disabilities if remained untreated, the initiation of thyroid hormone replacement in all infants who present an abnormal thyroid hormone profile might be unnecessary. Levothyroxine supplementation for "persistent or profound TSH elevation and/ or low T4 level" is usually recommended, although the criteria for treating these conditions have not been clearly established. ${ }^{3)}$ The screening methods used in several studies on thyroid function of preterm infants in Korea are summarized in Table 4.

Administration of levothyroxine to preterm infants in Japan has been suggested to cause late-onset circulatory collapse. ${ }^{52,53)}$ Kawa et al. $^{53)}$ reported that the administration of levothyroxine was associated with an increased risk of late-onset circulatory collapse in VLBW infants, and that the first 2 weeks after the initiation of supplementation could be a high-risk period. However, the causal relationship was not proven in other studies. ${ }^{54-56)}$ Although there is incomplete evidence, but Japanese guidelines have recommended that hypothyroxinemia in LBW infants should not be treated with levothyroxine.

Table 3. Several guidelines on screening for congenital hypothyroidism in preterm or low birth weight infants

\begin{tabular}{|c|c|c|c|c|}
\hline Variable & ESPE $^{*}$ & BSPED/BAPM/UKNSLN & JSPE & ISPAE \\
\hline Released year & 2014 & 2014 & 2014 & 2018 \\
\hline Subjects & $\begin{array}{l}\text { Preterm neonates; } \\
\text { LBW and VLBW neonates }\end{array}$ & $\begin{array}{l}\text { Preterm infants born at } \\
<32 \text { weeks gestation }\end{array}$ & $\begin{array}{l}\text { Premature neonates; infants of } \\
\text { birth weight }<2,000 \mathrm{~g}\end{array}$ & Preterm; LBW/VLBW infants \\
\hline $\begin{array}{l}\text { Timing of } \\
\text { 2nd screening test }\end{array}$ & $\begin{array}{l}\text { About } 2 \text { weeks of age, } \\
\text { or } 2 \text { weeks after } \\
\text { the first screening test }\end{array}$ & $\begin{array}{l}28 \text { Days postnatal age or } \\
\text { discharge home }\end{array}$ & $\begin{array}{l}\text { One month after birth, when } \\
\text { their body weight reaches } \\
2,500 \mathrm{~g} \text {, or at discharge from } \\
\text { the hospital }\end{array}$ & $\begin{array}{l}4 \text { Weeks of age (or at } 2 \text { weeks } \\
\text { of age if discharged early) }\end{array}$ \\
\hline $\begin{array}{l}\text { Method of } \\
\text { 2nd screening test }\end{array}$ & Whole blood TSH & Whole blood TSH & Whole blood TSH & Whole blood TSH \\
\hline Comments & $\begin{array}{l}\text { The criteria defining a positive } \\
\text { screening test result should } \\
\text { be adapted for the analytical } \\
\text { parameters measured, } \\
\text { the method used, and the age } \\
\text { at sampling and maturity of } \\
\text { the infant. }\end{array}$ & $\begin{array}{l}\text { The policy is based on } \\
\text { gestational age criteria. }\end{array}$ & $\begin{array}{l}\text { Infants with delayed TSH } \\
\text { elevation in the second mass } \\
\text { screening should undergo a } \\
\text { detailed examination. } \\
\text { Hypothyroxinemia in low birth } \\
\text { weight infants should not be } \\
\text { treated with levothyroxine. }\end{array}$ & $\begin{array}{l}\text { The final TSH cutoffs for } \\
\text { preterm, LBWNLBW infants } \\
\text { and twins remain the same as } \\
\text { for term infants. (see below }{ }^{+} \text {) }\end{array}$ \\
\hline
\end{tabular}

ESPE, European Society for Paediatric Endocrinology; BSPED, British Society of Paediatric Endocrinology; BAPM, British Association of Perinatal Medicine; UKNSLN, United Kingdom Newborn Screening Laboratory Network; JSPE, Japanese Society for Pediatric Endocrinology; ISPAE, Indian Society for Pediatric and Adolescent Endocrinology; LBW, low birth weight (1,500-2,500 g); VLBW, very low birth weight $(<1,500 \mathrm{~g})$; T4, thyroxine; TSH, thyrotropin.

*On behalf of European Society for Paediatric Endocrinology, Pediatric Endocrine Society, Latin American Society for Pediatric Endocrinology, Japanese Society for Pediatric Endocrinology, Australasian Paediatric Endocrine Group, Asia Pacific Paediatric Endocrine Society, Indian Society for pediatric and adolescent Endocrinology, and the Congenital Hypothyroidism Consensus Conference Group. ${ }^{\dagger}$ Criteria on venous confirmatory sample results for initiation of levothyroxine therapy in ISPAE guideline: (1) low T4 ( $\left.<8 \mu \mathrm{g} / \mathrm{dL}\right)$ or low free $\mathrm{T} 4(<1.1 \mathrm{ng} / \mathrm{dL})$ irrespective of TSH, (2) mild low T4 $(<10 \mu \mathrm{g} / \mathrm{dL})$ or low FT4 $(<1.17 \mathrm{ng} / \mathrm{dL})$ in the presence of elevated venous TSH $>20$ $\mathrm{mIU} / \mathrm{L}$ if age is $<2$ weeks and $>10 \mathrm{mIU} / \mathrm{L}$ if age is $>2$ weeks, (3) normal T4/ free T4 with persistently elevated TSH $>10 \mathrm{mIU} / \mathrm{L}$ at age $>3$ weeks. 
Table 4. The screening methods used in articles on thyroid function of preterm infants in Korea

\begin{tabular}{|c|c|c|c|}
\hline Study & Subject & Screening method & Definition of hypothyroidism \\
\hline Chung et al., 2009 & $\mathrm{GA}<32$ weeks & $\begin{array}{l}\text { Initial test: serum TSH and T4 within } 10 \text { days } \\
\text { Repeat test: } 2-4 \text { weeks after the first test }\end{array}$ & $\begin{array}{l}\text { Serum free T4 }<0.7 \mathrm{mg} / \mathrm{dL} \text { and TSH }>10 \mathrm{mlU} / \mathrm{L}, \\
\text { or TSH }>30 \text { in conjunction with any level of free T4 }\end{array}$ \\
\hline Lim et al., 2014 & $\mathrm{BW}<1,500 \mathrm{~g}$ & $\begin{array}{l}\text { Initial test: newborn screening with blood spot within } \\
7 \text { days after birth } \\
\text { Repeat test: (1) normal newborn test: serum free T4 and } \\
\text { TSH at } 4 \text { weeks of age; (2) abnormal newborn test: } \\
\text { serum free T4 and TSH at } 2 \text { weeks of age }\end{array}$ & Not defined \\
\hline Oh et al., 2014 & $\mathrm{GA}<35$ weeks & $\begin{array}{l}\text { Initial: newborn screening with blood spot } \\
\text { Repeat test: (1) normal newborn test: serum free T4, T3 and } \\
\text { TSH at } 4 \text { weeks of age; (2) abnormal newborn test: } \\
\text { serum free T4,T3 and TSH at } 2 \text { weeks of age }\end{array}$ & Not defined \\
\hline Lee et al., 2015 $5^{24)}$ & $\mathrm{BW}<1,500 \mathrm{~g}$ & $\begin{array}{l}\text { Serum TSH and free T4 at } 7 \text { days } \\
\text { Repeat test: (1) normal: at } 4 \text { weeks of age and at discharge; } \\
\text { (2) abnormal: } 2 \text { weeks after the previous test }\end{array}$ & Serum free $\mathrm{T} 4<0.7 \mathrm{mg} / \mathrm{dL}$ with TSH $>20 \mathrm{mIU} / \mathrm{L}$ \\
\hline Jung et al., 2016 ${ }^{58)}$ & $\mathrm{BW}<1,500 \mathrm{~g}$ & $\begin{array}{l}\text { Serum TSH and free T4 at the age of } 7 \text { days, 2-4 weeks, } \\
\text { and prior to discharge from NICU }\end{array}$ & $\begin{array}{l}\text { Within } 7 \text { days: TSH }>20 \mu \mathrm{U} / \mathrm{mL} \text { and free T4 were } \\
<1.0 \mathrm{ng} / \mathrm{dL} ; 2-4 \text { weeks: TSH }>6.0 \mu \mathrm{U} / \mathrm{mL} \\
\text { and free T4 }<0.7 \mathrm{ng} / \mathrm{dL} \\
\text { Isolated high TSH ( }>9.0 \mu \mathrm{U} / \mathrm{mL} \text { ) levels were } \\
\text { considered abnormal after } 4 \text { weeks of age }\end{array}$ \\
\hline
\end{tabular}

GA, gestational age; BW, birthweight; T4, thyroxine; T3, triiodothyronine; TSH, thyrotropin; NICU, neonatal intensive care unit.

The starting dose for infants with delayed TSH elevation is often lower than the dose used to treat typical congenital primary hypothyroidism $(8-10 \mu \mathrm{g} / \mathrm{kg}$ per day vs. $10-15 \mu \mathrm{g} /$ $\mathrm{kg}$ per day), while the dose for preterm neonates with obvious primary hypothyroidism is similar to that for term neonates. ${ }^{49)}$

Re-evaluation of thyroid function is recommended for all preterm infants with normally located gland or for cases in which no etiological diagnostic assessment was carried out during early infancy. ${ }^{5}$ Re-evaluation is possible before 3 years of age in preterm infants. Lim et al. ${ }^{57)}$ and Jung et al. ${ }^{58)}$ reported that discontinuation of thyroxine supplementation is possible at the age of $\leq 2$ when low doses of levothyroxine administration could be successfully maintained.

Some infants present persistent thyroid dysfunction after discontinuation of thyroid hormone replacement, although most thyroid dysfunctions among preterm infants are transient. Vigone et al ${ }^{59)}$ reported that among 23 preterm infants diagnosed with congenital hypothyroidism by carrying out the screening procedure, 12 infants were diagnosed either with permanent hypothyroidism or persistent hyperthyrotropinemia. Most infants with permanent hypothyroidism were associated with twin birth, assisted birth, lower GA, and severe postnatal complications-related to prematurity. Thus, preterm infants, particularly those having the abovementioned features, should be carefully followed up by thyroid function testing.

\section{Conclusions}

Preterm infants have a higher incidence of thyroid dysfunction that includes a unique form of hypothyroidism. While several guidelines have been published on screening for congenital hypothyroidism over the recent decades, optimal management and long-term outcomes of thyroid dysfunction in preterm infants remain unclear. Thyroid function in preterm infants is affected by various factors including immaturity of the H-P-T axis, postnatal medical condition, and regional iodine supply; thus, advanced clinical guidelines that can take these conditions into account are warranted.

\section{Conflicts of interest}

No potential conflict of interest relevant to this article was reported.

\section{References}

1. Dussault JH, Coulombe P, Laberge C, Letarte J, Guyda H, Khoury K. Preliminary report on a mass screening program for neonatal hypothyroidism. J Pediatr 1975;86:670-4.

2. DH Lee. The prevalence of pediatric endocrine and metabolic diseases in Korea. Korean J Pediatr 2008;51:55963.

3. Mitchell ML, Hsu HW; Massachusetts Pediatric Endocrine Work Group. Unresolved issues in the wake of newborn screening for congenital hypothyroidism. J Pediatr 2016;173:228-31.e1.

4. American Academy of Pediatrics, Rose SR; Section on Endocrinology and Committee on Genetics, American Thyroid Association, Brown RS; Public Health Committee, Lawson Wilkins Pediatric Endocrine Society, Foley T, et al. Update of newborn screening and therapy for congenital hypothyroidism. Pediatrics 2006;117:2290-303.

5. Léger J, Olivieri A, Donaldson M, Torresani T, Krude H, van Vliet G, et al. European Society for Paediatric Endocrinology consensus guidelines on screening, diagnosis, and management of congenital hypothyroidism. Horm Res Paediatr 2014;81:80-103.

6. Mass Screening Committee; Japanese Society for Pediatric 
Endocrinology; Japanese Society for Mass Screening, Nagasaki K, Minamitani K, Anzo M, et al. Guidelines for mass screening of congenital hypothyroidism (2014 revision). Clin Pediatr Endocrinol 2015;24:107-33.

7. Desai MP, Sharma R, Riaz I, Sudhanshu S, Parikh R, Bhatia V. Newborn screening guidelines for congenital hypothyroidism in India: recommendations of the Indian Society for Pediatric and Adolescent Endocrinology (ISPAE) - Part I: Screening and Confirmation of Diagnosis. Indian J Pediatr 2018;85:440-7.

8. Uhrmann S, Marks KH, Maisels MJ, Friedman Z, Murray F, Kulin HE, et al. Thyroid function in the preterm infant: a longitudinal assessment. J Pediatr 1978;92:968-73.

9. Hillman NH, Kallapur SG, Jobe AH. Physiology of transition from intrauterine to extrauterine life. Clin Perinatol 2012;39:769-83.

10. Fisher DA. Thyroid system immaturities in very low birth weight premature infants. Semin Perinatol 2008;32:387-97.

11. Mandel SJ, Hermos RJ, Larson CA, Prigozhin AB, Rojas DA, Mitchell ML. Atypical hypothyroidism and the very low birthweight infant. Thyroid 2000;10:693-5.

12. Scratch SE, Hunt RW, Thompson DK, Ahmadzai ZM, Doyle LW, Inder TE, et al. Free thyroxine levels after very preterm birth and neurodevelopmental outcomes at age 7 years. Pediatrics 2014;133:e955-63.

13. Jacobsen BB, Peitersen B, Andersen HJ, Hummer L. Serum concentrations of thyroxine-binding globulin, prealbumin and albumin in healthy fullterm, small-for-gestational age and preterm newborn infants. Acta Paediatr Scand 1979;68:49-55.

14. Delahunty C, Falconer S, Hume R, Jackson L, Midgley P, Mirfield M, et al. Levels of neonatal thyroid hormone in preterm infants and neurodevelopmental outcome at $51 / 2$ years: millennium cohort study. J Clin Endocrinol Metab 2010;95:4898-908.

15. van Wassenaer AG, Kok JH, de Vijlder JJ, Briët JM, Smit BJ, Tamminga $P$, et al. Effects of thyroxine supplementation on neurologic development in infants born at less than 30 weeks' gestation. N Engl J Med 1997;336:21-6.

16. Briët JM, van Wassenaer AG, Dekker FW, de Vijlder JJ, van Baar A, Kok JH. Neonatal thyroxine supplementation in very preterm children: developmental outcome evaluated at early school age. Pediatrics 2001;107:712-8.

17. van Wassenaer AG, Westera J, Houtzager BA, Kok JH. Tenyear follow-up of children born at $<30$ weeks' gestational age supplemented with thyroxine in the neonatal period in a randomized, controlled trial. Pediatrics 2005;116:e613-8.

18. van Wassenaer-Leemhuis A, Ares S, Golombek S, Kok J, Paneth N, Kase J, et al. Thyroid hormone supplementation in preterm infants born before 28 weeks gestational age and neurodevelopmental outcome at age 36 months. Thyroid 2014;24:1162-9.

19. Iijima S. Current knowledge of transient hypothyroxinemia of prematurity: to treat or not to treat? J Matern Fetal Neonatal Med 2018 Feb 22:1-7.

20. Yamamoto A, Kawai M, Iwanaga K, Matsukura T, Niwa
F, Hasegawa T, et al. Response to thyrotropin-releasing hormone stimulation tests in preterm infants with transient hypothyroxinemia of prematurity. J Perinatol 2015;35:7258.

21. Larson C, Hermos R, Delaney A, Daley D, Mitchell M. Risk factors associated with delayed thyrotropin elevations in congenital hypothyroidism. J Pediatr 2003;143:587-91.

22. Cavarzere P, Camilot M, Popa FI, Lauriola S, Teofoli F, Gaudino R, et al. Congenital hypothyroidism with delayed TSH elevation in low-birth-weight infants: incidence, diagnosis and management. Eur J Endocrinol 2016;175:395-402.

23. Chung HR, Shin CH, Yang SW, Choi CW, Kim BI, Kim EK, et al. High incidence of thyroid dysfunction in preterm infants. J Korean Med Sci 2009;24:627-31.

24. Lee JH, Kim SW, Jeon GW, Sin JB. Thyroid dysfunction in very low birth weight preterm infants. Korean J Pediatr 2015;58:224-9.

25. Woo HC, Lizarda A, Tucker R, Mitchell ML, Vohr B, Oh W, et al. Congenital hypothyroidism with a delayed thyroidstimulating hormone elevation in very premature infants: incidence and growth and developmental outcomes. J Pediatr 2011;158:538-42.

26. Hollanders JJ, Israëls J, van der Pal SM, Verkerk PH, Rotteveel J, Finken MJ, et al. No association between transient hypothyroxinemia of prematurity and neurodevelopmental outcome in young adulthood. J Clin Endocrinol Metab 2015;100:4648-53.

27. Williams FL, Simpson J, Delahunty C, Ogston SA, BongersSchokking JJ, Murphy N, et al. Developmental trends in cord and postpartum serum thyroid hormones in preterm infants. J Clin Endocrinol Metab 2004;89:5314-20.

28. Kester MH, Martinez de Mena R, Obregon MJ, Marinkovic D, Howatson A, Visser TJ, et al. Iodothyronine levels in the human developing brain: major regulatory roles of iodothyronine deiodinases in different areas. J Clin Endocrinol Metab 2004;89:3117-28.

29. Fisher DA. Physiological variations in thyroid hormones: physiological and pathophysiological considerations. Clin Chem 1996;42:135-9.

30. Ares S, Pastor I, Quero J, Morreale de Escobar G. Thyroid gland volume as measured by ultrasonography in preterm infants. Acta Paediatr 1995;84:58-62.

31. Zung A, Bier Palmon R, Golan A, Troitzky M, EventovFriedman S, Marom R, et al. Risk factors for the development of delayed TSH elevation in neonatal intensive care unit newborns. J Clin Endocrinol Metab 2017;102:3050-5.

32. Delange F. Optimal iodine nutrition during pregnancy, lactation and the neonatal period. Int J Endocrinol Metab 2004:2:1-12.

33. Delange $F$. Iodine requirements during pregnancy, lactation and the neonatal period and indicators of optimal iodine nutrition. Public Health Nutr 2007;10(12A):1571-80.

34. Ares S, Escobar-Morreale HF, Quero J, Durán S, Presas MJ, Herruzo R, et al. Neonatal hypothyroxinemia: effects of iodine intake and premature birth. J Clin Endocrinol 
Metab 1997;82:1704-12.

35. Ibrahim M, de Escobar GM, Visser TJ, Durán S, van Toor $\mathrm{H}$, Strachan J, et al. Iodine deficiency associated with parenteral nutrition in extreme preterm infants. Arch Dis Child Fetal Neonatal Ed 2003;88:F56-7.

36. Linder N, Davidovitch N, Reichman B, Kuint J, Lubin D, Meyerovitch J, et al. Topical iodine-containing antiseptics and subclinical hypothyroidism in preterm infants. J Pediatr 1997;131:434-9.

37. Smith VC, Svoren BM, Wolfsdorf JI. Hypothyroidism in a breast-fed preterm infant resulting from maternal topical iodine exposure. J Pediatr 2006;149:566-7.

38. Chung HR, Shin CH, Yang SW, Choi CW, Kim BI. Subclinical hypothyroidism in Korean preterm infants associated with high levels of iodine in breast milk. J Clin Endocrinol Metab 2009;94:4444-7.

39. Melmed S, Polonsky KS, Larsen PR, Kronenberg HM, editors. Williams textbook of endocrinology. 13th ed. Philadelphia (PA): Saunders Elsevier; 2015; 334-5.

40. Moon S, Kim J. Iodine content of human milk and dietary iodine intake of Korean lactating mothers. Int J Food Sci Nutr 1999;50:165-71.

41. Aitken J, Williams FL. A systematic review of thyroid dysfunction in preterm neonates exposed to topical iodine. Arch Dis Child Fetal Neonatal Ed 2014;99:F21-8.

42. Ghirri P, Lunardi S, Boldrini A. Iodine supplementation in the newborn. Nutrients 2014;6:382-90.

43. Agostoni C, Buonocore G, Carnielli VP, De Curtis M, Darmaun D, Decsi T, et al. Enteral nutrient supply for preterm infants: commentary from the European Society of Paediatric Gastroenterology, Hepatology and Nutrition Committee on Nutrition. J Pediatr Gastroenterol Nutr 2010;50:85-91.

44. Zimmermann MB, Crill CM. Iodine in enteral and parenteral nutrition. Best Pract Res Clin Endocrinol Metab 2010;24:143-58.

45. Greene HL, Hambidge KM, Schanler R, Tsang RC. Guidelines for the use of vitamins, trace elements, calcium, magnesium, and phosphorus in infants and children receiving total parenteral nutrition: report of the Subcommittee on Pediatric Parenteral Nutrient Requirements from the Committee on Clinical Practice Issues of the American Society for Clinical Nutrition. Am J Clin Nutr 1988;48:1324-42.

46. Koletzko B, Goulet O, Hunt J, Krohn K, Shamir R; Parenteral Nutrition Guidelines Working Group, et al. Guidelines on Paediatric Parenteral Nutrition of the European Society of Paediatric Gastroenterology, Hepatology and Nutrition (ESPGHAN) and the European Society for Clinical Nutrition and Metabolism (ESPEN), Supported by the European Society of Paediatric Research (ESPR). J Pediatr Gastroenterol Nutr 2005;41 Suppl 2:S1-87.

47. NHS newborn blood spot screening programme. A laboratory guide to newborn screening in the UK for congenital hypothyroidism [Internet]. UK National Screening Committee (Part of Public Health England) publication;
2014 [cited 2019 Jan 14]. Available from: https://assets. publishing.service.gov.uk/government/uploads/system/ uploads/attachment_data/file/753471/Congenital_ hypothyroidism_lab_guide.pdf.

48. Vincent MA, Rodd C, Dussault JH, Van Vliet G. Very low birth weight newborns do not need repeat screening for congenital hypothyroidism. J Pediatr 2002;140:311-4.

49. LaFranchi S. Thyroid physiology and screening in preterm infants [Internet]. Uptodate; 2018 [cited 2019 Jan 16]. Available from: https://www.uptodate.com/contents/ thyroid-physiology-and-screening-in-preterm-infants.

50. Korada M, Pearce MS, Ward Platt MP, Avis E, Turner S, Wastell H, et al. Repeat testing for congenital hypothyroidism in preterm infants is unnecessary with an appropriate thyroid stimulating hormone threshold. Arch Dis Child Fetal Neonatal Ed 2008;93:F286-8.

51. Clark SJ, Deming DD, Emery JR, Adams LM, Carlton EI, Nelson JC. Reference ranges for thyroid function tests in premature infants beyond the first week of life. J Perinatol 2001;21:531-6.

52. Yagasaki H, Kobayashi K, Nemoto A, Naito A, Sugita K, Ohyama K. Late-onset circulatory dysfunction after thyroid hormone treatment in an extremely low birth weight infant. J Pediatr Endocrinol Metab 2010;23:153-8.

53. Kawai M, Kusuda S, Cho K, Horikawa R, Takizawa F, Ono $\mathrm{M}$, et al. Nationwide surveillance of circulatory collapse associated with levothyroxine administration in very-lowbirthweight infants in Japan. Pediatr Int 2012;54:177-81.

54. Shimokaze T, Saito E, Akaba K. Increased incidence of lateonset circulatory collapse after changing clinical practice: a retrospective investigation of causative factors. Am J Perinatol 2015;32:1169-76.

55. Lee JA, Choi CW, Kim EK, Kim HS, Kim BI, Choi JH. Lateonset hypotension and late circulatory collapse due to adrenal insufficiency in preterm infants with gestational age less than 32 weeks. J Korean Soc Neonatol 2011;18:21120.

56. Lee WJ, Kim MY, Cho HJ, Lee JS, Son DW. Clinical features of late-onset circulatory collapse in preterm infants. Korean J Perinatol 2013;24:148-57.

57. Lim G, Lee YK, Han HS. Early discontinuation of thyroxine therapy is possible in most very low-birthweight infants with hypothyroidism detected by screening. Acta Paediatr 2014;103:e123-9.

58. Jung JM, Jin HY, Chung ML. Feasibility of an early discontinuation of thyroid hormone treatment in very-low-birthweight infants at risk for transient or permanent congenital hypothyroidism. Horm Res Paediatr 2016;85:131-9.

59. Vigone MC, Caiulo S, Di Frenna M, Ghirardello S, Corbetta C, Mosca F, et al. Evolution of thyroid function in preterm infants detected by screening for congenital hypothyroidism. J Pediatr 2014;164:1296-302.

60. Oh KW, Koo MS, Park HW, Chung ML, Kim MH, Lim G. Establishing a reference range for triiodothyronine levels in preterm infants. Early Hum Dev 2014;90:621-4. 